\title{
İlkokula Hazırlık Becerilerine İlişkin Okul Öncesi ve Birinci Sınıf Öğretmenleri ile Öğretmen Adaylarının Görüşleri*
}

\author{
Views of Preschool, Primary School and Preservice Teachers on School \\ Readiness Skills
}

\begin{abstract}
Nevra Atış-Akyol ${ }^{1}$, Nurbanu Parpucu², Nefise Semra Erkan ${ }^{3}$
Makale Geçmişi

Geliş : 17 Haziran 2020

Düzeltme : 22 Ekim 2020

Kabul : 30 Ekim 2020

Makale Türü

Arastruma Makalesi

Öz: Araștırmanın amacı, okul öncesi öğretmenleri ve birinci sınıf öğretmenleri ile okulöncesi ve sınıf öğretmenliği 4. sınıf öğrencilerinin, çocukların ilkokula geçişte sahip olması gereken ilkokula hazırlık becerilerine ilişkin görüşlerini incelemektir. Ayrıca araştırmanın bir diğer amacı ise, katılımcıların ilkokula hazırlık becerilerinden hangilerine daha çok önem verdiklerini belirlemektir. Araştırma betimsel tarama modelinde tasarlanmıştır. Kolay ulaşılabilir örnekleme yolu ile araştırmaya 80 okul öncesi öğretmeni, 50 sınıf öğretmeni, 51 okul öncesi öğretmen adayı ve 88 sınıf öğretmen adayı olmak üzere toplam 269 kişi katılmıştır. Araştırmada veri toplama aracı olarak araştırmacılar tarafindan geliştirilen "Genel Bilgi Formu" ve "İlkokula Hazırlık Becerileri Anketi” kullanılmıştır. Araştırma kapsamında geliştirilen anket için ulusal ve uluslararası alanyazın örnekleri incelenmiş ve uzman görüşleri alınmışır. Verilerin analizinde ortalama, yüzde ve frekans kullanılmıştır. Araştırma sonucunda, okul öncesi öğretmenlerinin, sınıf öğretmenlerinin, okul öncesi ve sınıf öğretmen adaylarının ilkokula hazırlık becerilerine ilişkin görüşleri incelendiğinde en yüksek ortalamanın; öz bakım becerileri alanına ait olduğu görülmüştür. Sınıf öğretmenliği adaylarının ise ilkokula hazırlık becerilerine ilişkin görüşleri incelendiğinde en yüksek ortalamanın fiziksel gelişim alanına ait olduğu görülmüştür. Bu bilgiler ışı̆̆ında alan yazında ilkokula hazırlık becerileri ile ilgili gelişim alanlarına yönelik olarak hem örneklem gruplarında hem de gelişim alanlarının vurgulanması noktasında benzerlikler kadar farklılıklar da olduğu saptanmıştır. Bu farklı görüşlerin ilkokula hazırlık kavramının çok yönlü yapısından kaynaklandığı düşünülmektedir.
\end{abstract}

Anahtar Kelimeler: İlkokula hazırlık, İlkokula hazırlık becerileri, Okul öncesi öğretmeni, Sınıf öğretmeni, Öğretmen adayı

Abstract: The aim of this study is to examine the views of preschool, primary school and preservice teachers that are at senior grade of the university on school readiness skills that children should have in transition to primary school. In addition, it was aimed to determine which of school readiness skills was given more importance to by the participants of the study. The study aiming to investigate the views of preschool, primary school and preservice teachers was designed in survey model. Preschool teachers, primary school teachers and preservice teachers were included in the study through convenience sampling. The sample of the study consisted of 269 participants including 80 preschool teachers, 50 primary school teachers, 51 preschool teacher candidates and 88 primary school teacher candidates. In the research, "General Information Form" and School Readiness Skills Questionnaire developed by the researchers were used as data collection tools. In the analysis of the data, medium, percentage and frequency were used. As a result of the research, when the views of preschool teachers, primary school teachers, preschool and primary svhool teacher candidates about school readiness skills were examined, the highest average was self-care skills. However, it is seen that the highest average belongs to physical development.for preservice primary school teachers. It was seen that there were differences and similarities in the sample groups in emphasizing the development areas regarding school readiness skills in the literature. It is thought that these different opinions stem from the multifaceted structure of the concept of school readiness.

Keywords: School readiness, School readiness skills, Preschool teachers, Primary school teacher, Teacher candidate

\footnotetext{
*Bu çalışmanın bir bölümü 2-5 Ekim 2019 tarihleri arasında düzenlenen 6. Uluslararası Okul Öncesi Eğitim Kongresinde “sözlü bildiri” olarak sunulmuştur.

Başlıca Yazar: Nevra Atış Akyol

${ }^{1}$ Sivas Cumhuriyet Üniversitesi, Eğitim Fakültesi, Temel Eğitim Bölümü, naakyol@cumhuriyet.edu.tr, ORCID: https://orcid.org/0000-0003-4697$847 \mathrm{X}$

${ }^{2}$ Hacettepe Üniversitesi, Eğitim Fakültesi, Temel Eğitim Bölümü, nurbanuparpucu@gmail.com, ORCID: https://orcid.org/0000-0002-4544-3927 3 İstanbul Gelişim Unniversitesi, Sağlık Bilimleri Yüksek Okulu, Çocuk Gelişimi Bölümü, nsemraerkan@gmail.com, ORCID: https://orcid.org/0000-0001-8968-7926
} 


\section{SUMMARY}

\section{Introduction}

Starting school is undoubtedly one of the most important turning points in the child's life. Because when the child starts school, he / she enters into a foreign school environment where he / she will spend a great time of the day from the family environment where he / she feels safe in every sense. only a part of preschool children receive education of children in Turkey for the first time considering that a large part of the time they start primary school of this foreign environment can be said to enjoy the experience. These children will be faced with the learning of academic skills such as literacy and mathematics, as well as social skills such as attending planned activities in the school, following teacher's guidelines and school rules, developing positive peer relationships. Many studies show that school performance in primary school is associated with a successful transition from kindergarten to primary school (Dockett and Perry, 2003a, 2004; Ramey and Ramey, 1998, Alexander and Entwisle, 1988). In order for the child to meet the requirements of transition to school and adapt to this new environment, he or she must have the skills of preparing for school. The aim of this study is to examine the views of preschool, primary school and preservice teachers that are at senior grade of the university on school readiness skills that children should have in transition to primary school. In addition, it was aimed to determine which of school readiness skills was given more importance to by the participants of the study.

\section{Method}

The study aiming to investigate the views of preschool, primary school and preservice teachers was designed in survey model. Preschool teachers, primary school teachers and preservice teachers were included in the study through convenience sampling. Volunteerism principle was used in the study. The sample of the study consisted of 269 participants including 80 preschool teachers, 50 primary school teachers, 51 preschool teacher candidates and 88 primary school teacher candidates.

In the research, "General Information Form" and School Readiness Skills Questionnaire developed by the researchers were used as data collection tools.

For the development of the questionnaire, wide range of literature review was conducted before determining the skills required for school readiness. Then, a total of 32 participants consisting of seven preschool teachers, seven first grade teachers, nine preschool teacher candidates and nine primaru teacher candidates were given an open-ended question and asked to write their thoughts about school readiness skills in the form of composition. The answers of the participants to the open-ended questions were classified and listed by the researchers according to the appropriate development areas and the survey items were created. In this way, a draft questionnaire consisting of 6 sub-dimensions and 57 items was created. The $\mathrm{draft}$ questionnaire was presented to the field experts working in the fields of preschool, classroom teaching, assessment and Turkish language to ensure the validity of language and scope. According to expert opinions, 57 survey items were reorganized as 26 items. Then, the pre-study with two preschool and two first grade 
teachers, two preschool teacher candidates and two primary school teacher candidates were conducted to check the comprehensibility of the questionnaire items. As a result of the preliminary study, the 26-item questionnaire was finalized.

This 5-point Likert-type questionnaire includes six dimensions related to school readiness. These dimensions are; Physical Development, Social and Emotional Development, Language Development, Approaches to Learning, Cognitive Development and Self Care Skills". These dimensions are based on five dimensions of school readiness identified in the National Education Goals Panel (NEGP, 1995). Physical development dimension of the questionnaire includes 4 item; social and emotional development dimension had 6 items, language development dimension includes 4 items; approaches to learning dimension inludes 3 items; cognitive development dimension includes 4 items; and self-care skills includes 5 items. Responses to the survey items; totally disagree (1), disagree (2), undecided (3), agree (4), and fully agree (5). The questionnaire is administered individually and each questionnaire takes approximately 10 minutes.

In the analysis of the data, medium, percentage and frequency were used.

\section{Results}

As a result of the research, when the views of preschool teachers, primary school teachers and preschool teacher candidates about school readiness skills were examined, the highest average was self-care skills. As a result of the research, when the views of preservice primary school teachers about school readiness skills were examined, it is seen that the highest average belongs to physical development.

In line with these results, it is seen that preschool teachers, primary school teachers, preschool teacher candidates and primary school teacher candidates stated some common skills in the skills with the highest average in the development areas related to school readiness skills. In approach toward learning skills, "willingness to learn" was common. In language development "expressing feelings and thoughts in a clear and smooth Turkish" skill, and in self-care skills, "making toilet by himself/herself self-cleaning skills" was found as common. It is seen that the ability to have conceptual knowledge in cognitive development is determined as the highest average skill by preschool teachers, classroom teachers and classroom teacher candidates. On the other hand, it is seen that preschool teacher candidates determine the cause-effect relationship between the events as the highest average skill in this field of development. In the field of social emotional development, preschool and primary school teacher candidates gave the highest average to the ability to express their feelings correctly when they were upset, rejoiced or scared. Preschool teachers gave the highest average to the ability to adapt to school without worrying about separation from parents while primary school teachers gave that to follow the instructions of teacher.In the field of physical development, all participants gave the highest score to the different skills. When the total average of the development areas is examined, preschool teachers, classroom teachers and preschool teacher candidates gave the highest average to "self-care skills" field, while primary school teacher candidates gave the highest average to "physical development” field. 


\section{Conclusion and Discussion}

In the light of all this, it was found that there were differences and similarities emphasizing the development areas related to school readiness skills. It is thought that these different opinions stem from the multifaceted structure of the concept of school readiness. The reason of this is that school readiness is a concept consisting of family, teacher (preschool teacher, classroom teacher), child and community stakeholders and emphasizes all development areas. Therefore, these differences may be due to the experiences and expectations of the sample groups. 


\section{GİRİŞ}

Okula başlamak, kuşkusuz çocuğun yaşamındaki en önemli dönüm noktalarından birisidir. Çünkü çocuk okula başlarken, kendini her anlamda güvende hissettiği aile ortamından, gününün büyük bir zaman dilimini geçireceği yabancı bir okul ortamına girer. Türkiye'deki çocukların bir bölümünün okul öncesi eğitim aldığı düşünüldüğünde okul öncesi eğitim almamış çocukların ilkokula başladıkları zaman ilk kez yabancı ortam deneyimini yaşayacağı söylenebilir. Bu çocuklar, okulda planlanmış etkinliklere katılmak, öğretmenin yönergelerine ve okul kurallarına uymak, olumlu akran ilişkileri geliştirmek gibi sosyal becerilerin yanı sıra okuma-yazma, matematik gibi akademik becerileri de öğrenme durumuyla karşı karşıya kalacaktır. Pek çok araştırma, ilkokul dönemindeki okul performansının çocuğun anasınıfından ilkokula başarılı bir geçiş yapmasıyla ilişkili olduğunu göstermektedir (Dockett ve Perry, 2003a, 2004; Ramey ve Ramey, 1998; Alexander ve Entwisle, 1988). Çocuğun okula geçişin gereklerini yerine getirebilmesi ve bu yeni ortama uyum sağlayabilmesi için okula hazırlık becerilerine sahip olması gerekmektedir.

Okula hazırlık genel anlamıyla "bir görevi güçlükle karşılaşmadan başarabilmek için gerekli Özelliklere sahip olma durumudur” (Erkan, 2011). Okula hazırlık becerileri, Amerika'da Ulusal Eğitim Hedefleri Paneli’nde (National Education Goals Panel, NEGP, 1995) sağlık ve fiziksel gelişim, duygusal ve sosyal yeterlik, öğrenme yaklaşımları, dil gelişimi ve iletişim becerileri, bilişsel kapasite ve genel bilgi şeklinde 5 temel alana yönelik beceriler olarak sınıflandırılmıştır. Erken çocukluk döneminde meydana gelen bu önemli beceriler gelişimsel ve etkileşimsel bir süreci içermektedir. Bu süreçte çocuklar akran grupları, aileleri, öğretmenleri ve okulları ve hatta bir bütün olarak toplumun tüm yapı taşları ile etkileşimde bulunmaktadır. Bu araştırmanın kuramsal çerçevesini de bu düşünceye yönelik olarak Bronfenbrenner'ın Ekolojik Teorisi oluşturmaktadır. Bronfenbrenner'ın kuramındaki temel ilke; çocukların yaşadıkları çevreden etkilendiği ve bu çevrenin de çocuğun gelişim sürecini yoğun bir şekilde etkilemesidir. Bronfenbrenner, çocuk gelişimi içerisinde yer alan ekolojik ortamın; mikrosistem, mezosistem, ekzosistem ve makrosistem şeklinde katmanlardan oluştuğunu ve bunun bireyler ve çevre arasında karşl11klı olarak büyüyen ve birlikte var olan organize bir sistem olduğunu belirtmektedir (Brofenbrenner, 1979).

Bronfenbrenner (1979), Balaban (1985) ve Edgar (1986), okula geçişte; ebeveynlerin, öğretmenlerin ve çocukların eşit birer ortak olarak çalıştıklarında en iyi sonuca ulaşıldığını belirterek, etkili okula geçiş programlarının ancak, ev, erken çocukluk eğitimi ve ilkokul ortamı ile ebeveynlerden, öğretmenlerden ve çocuklardan alınan girdiler arasında bağlantı kurulduğunda etkili olduğunu ifade etmişlerdir (Chan, 2012). UNICEF (2012), okula hazırlığ1; “çocuğun hazır olması”, “okulun hazır olması" ve "ailelerin hazır olması" şeklinde üç boyutta ele almaktadır. Bu boyutlardan çocuğun 
okula hazır olması için kuşkusuz ki en önemli katkı çocuğun okul öncesi eğitim kurumlarından faydalanmasıdır. Bu konuda Erkan ve Kırca, (2010)' nın yaptıklanı çalışmada; okul öncesi eğitim almış çocukların ilkokula hazırlık düzeylerini, okul öncesi eğitim kurumlarından faydalanmamış çocuklara göre daha yüksek olduğu bulunmuştur.

Çocuğun ilkokula başlamak için sahip olması gereken becerileri edinebilmesi için öncelikle çocuğun sahip olması gereken beceriler konusunda çocuğun ekolojik sisteminde yer alan tüm katmanlar açısından bir netliğin olması önemlidir. Bronfenberenner'ın ekolojik sistem yaklaşımına göre çocuğun mikrosistemi içerisinde yer alan aile ve mezosisteminde bulunan okul ortamındaki eğitimsel kültürün farklılaşabildiği belirtilmektedir (Okagaki ve Diamond, 2000). Dolayısıyla, akademik başarı ve ilkokula hazırlığa ilişkin çocuklardan beklenen gelissimsel hedefler de farklılaşmaktadır. Örneğin yapılan iki araştırmada, anasınıfı ve birinci sınıf öğretmenlerinin çocukları okula hazırlamak için gerekli olduğuna inandığı beceriler arasında uyuşmazlık olduğu sonucuna ulaşılmıştır (Opper, 1993; Wong, 2003). Okul öncesi öğretmenleri ve ilkokul öğretmenlerinin ilkokula hazırllğa ilişkin görüşlerinin incelendiği birçok araştırmada her iki branştaki öğretmenlerin benzer görüş ve beklentileri olduğu gibi farklı görüşleri de ortaya çıkmıştır (Şahin, Sak ve Tuncer 2013; Dereli, 2012; Kutluca Canbulat ve Yıldızbaş, Erden ve Altun, 2014). Benzer şekilde aileler ve öğretmenlerin görüşlerinin incelendiği çalışmalarda da farklı beklentiler söz konusudur. Piotrkowski (2004)' nin çalışmasında anasınıfı öğretmenleri, çocukların ilkokula hazırlık için sosyal ve duygusal yönleri vurgularken ailelerin, alfabe ve sayıları öğrenmek gibi akademik becerileri daha fazla vurguladıkları görülmüştür. Çocuklar bu beklentilere paralel şekilde ilkokula hazırlık için desteklenmektedir. Bu sebeple, çocuğun ilkokula yumuşak bir geçiş yapabilmesi için tüm paydaşların ilkokula hazırlıkla ilgili hangi beceriler, davranışlar ve tutumların gerektiği konusundaki görüşlerini bilmek önemlidir. Bu görüşler okulda öğretmenlerin öğretim uygulamaları ve çocukların okul başarıları üzerinde büyük bir etkiye sahiptir. $\mathrm{Bu}$ nedenle, okul öncesi öğretmenleri, öğretmen adayları; çocuklarla ilkokul sürecini yürütecek olan birinci sınıf öğretmenleri ve sınıf öğretmeni adaylarının ilkokula hazırlıkla ilgili görüşlerini belirlemenin, öğretmenlerin ilkokula hazırlık konusundaki gereksinimlerine uygun rehberlik, destek ve eğitim hizmetlerinin sağlanabilmesine ışık tutması açısından büyük önem taşımaktadır.

$\mathrm{Bu}$ noktadan hareketle araştırmada okulöncesi öğretmenleri ve birinci sınıf öğretmenleri ile, okulöncesi ve sınıf öğretmeni adaylarının çocukların ilkokula geçişte sahip olması gereken okula hazırlık becerilerine ilişkin görüşlerinin belirlenmesi amaçlanmıştır. 


\section{YÖNTEM}

Bu bölümde araştırmanın desenine, çalışma grubuna, veri toplama araçlarına, veri toplama sürecine ve verilerin analizine yönelik bilgiler yer almaktadır.

\section{Araştırma Deseni}

Okul öncesi ve birinci sınıf öğretmenleri ile okul öncesi ve sınıf öğretmeni adaylarının; çocukların ilkokula geçişte sahip olması gereken ilkokula hazırlık becerilerine ilişkin görüşlerini incelemeyi amaçlayan bu araştırmada betimsel tarama modeli kullanılmışır. Betimsel tarama modeli geçmişte olmuş ya da var olan bir durumun betimlenmesini amaçlamaktadır (Gay, Mills ve Airasian, 2009).

\section{Çalışma Grubu}

Araştırmanın çalısma grubunu, kolay ulaşılabilir örnekleme yolu ile belirlenen ve Ankara İlindeki resmi ve özel okullarda görev yapan okul öncesi öğretmenleri, birinci sınıf öğretmenleri ile resmi bir üniversitenin okul öncesi öğretmenliği ve sınıf öğretmenliği 4. sınıf öğrencileri oluşturmuştur. Kolay ulaşılabilir örnekleme; araştırmacının belirlediği örneklem büyüklüğ̈̈ne göre evrenden hem zaman hem de ekonomiklik kazanmak için kolay ulaşabildiği grubu seçmesidir (Şahin, 2014). Araştırmada gönüllülük ilkesi esas alınmış olup, araştırmanın örneklemini 80 okul öncesi öğretmeni, 50 birinci sınıf öğretmeni, 51 okul öncesi öğretmen adayı ve 88 sınıf öğretmeni adayı olmak üzere toplam 269 kişi oluşturmaktadır.

Araştırmada; okul öncesi öğretmenleri için “O.Ö.Ö.”, okul öncesi öğretmen adayları için “O.Ö.Ö.A.”, sınıf öğretmenleri için “S.Ö.”, sınıf öğretmeni adayları için "S.Ö.A.” şeklinde bazı k1saltmalara yer verilmiştir. Örneklem grubuna ait demografik bilgiler Tablo 1.'de sunulmuştur. 
Tablo 1. Örneklem Grubuna Ait Demografik Bilgiler

\begin{tabular}{|c|c|c|c|c|c|c|c|c|}
\hline $\begin{array}{l}\text { Okula Hazırlığa İlişkin } \\
\text { Ders Alma Durumu }\end{array}$ & \multicolumn{2}{|l|}{$\begin{array}{l}\text { O.Ö.Ö. } \\
\text { (f) }\end{array}$} & \multicolumn{2}{|c|}{$\begin{array}{l}\text { O.Ö.Ö.A. } \\
\text { (f) }\end{array}$} & \multicolumn{2}{|l|}{$\begin{array}{l}\text { S.Ö. } \\
\text { (f) }\end{array}$} & \multicolumn{2}{|l|}{$\begin{array}{l}\text { S.Ö.A. } \\
\text { (f) }\end{array}$} \\
\hline Lisans Dersi & \multicolumn{2}{|l|}{58} & \multicolumn{2}{|c|}{34} & \multicolumn{2}{|l|}{24} & \multicolumn{2}{|l|}{42} \\
\hline Seminer & \multicolumn{2}{|l|}{7} & \multicolumn{2}{|l|}{2} & \multicolumn{2}{|l|}{14} & \multicolumn{2}{|l|}{6} \\
\hline Atölye & \multicolumn{2}{|l|}{0} & \multicolumn{2}{|l|}{0} & \multicolumn{2}{|l|}{1} & \multicolumn{2}{|l|}{2} \\
\hline Diğer (bireysel) & \multicolumn{2}{|l|}{1} & \multicolumn{2}{|l|}{1} & \multicolumn{2}{|l|}{0} & \multicolumn{2}{|l|}{1} \\
\hline Eğitim almayan & \multicolumn{2}{|l|}{14} & \multicolumn{2}{|l|}{14} & \multicolumn{2}{|l|}{11} & \multicolumn{2}{|l|}{37} \\
\hline \multicolumn{9}{|l|}{ Cinsiyet } \\
\hline Kadin & \multicolumn{2}{|l|}{72} & \multicolumn{2}{|l|}{45} & \multicolumn{2}{|l|}{27} & \multicolumn{2}{|l|}{48} \\
\hline Erkek & \multicolumn{2}{|l|}{8} & \multicolumn{2}{|l|}{6} & \multicolumn{2}{|l|}{23} & \multicolumn{2}{|l|}{40} \\
\hline Toplam & \multicolumn{2}{|l|}{80} & \multicolumn{2}{|l|}{51} & \multicolumn{2}{|l|}{50} & \multicolumn{2}{|l|}{88} \\
\hline & \multicolumn{2}{|l|}{ O.Ö.Ö. } & O.Ö.ச̈ & & S.Ö. & & S.Ö.A. & \\
\hline & (ort) & $\begin{array}{l}\text { (min.- } \\
\text { mak.) }\end{array}$ & (ort.) & $\begin{array}{l}\text { (min.- } \\
\text { mak.) }\end{array}$ & (ort) & $\begin{array}{l}\text { (min.- } \\
\text { mak.) }\end{array}$ & (ort.) & $\begin{array}{l}\text { (min..- } \\
\text { mak) }\end{array}$ \\
\hline Yaş & 30 & $21-62$ & 22 & $21-25$ & 34 & $24-50$ & 22 & $20-29$ \\
\hline Mesleki Deneyim Y11 & 8 & $0-30$ & - & - & 11 & $1-29$ & - & - \\
\hline
\end{tabular}

Tablo 1`de görüldüğü üzere okula hazırllğga ilişkin okul öncesi öğretmenlerinin 58`i, okul öncesi öğretmen adaylarının 34 `u, sınıf öğretmenlerin 24`u ve sınıf öğretmen adaylarının 42 `si lisans dersi aldığını belirtmiştir. Okul öncesi öğretmenlerinin 7`si, okul öncesi öğretmen adaylarının 2`si, sınıf öğretmenlerinin 14`u ve sınıf öğretmen adaylarının 6`si seminer almıştır.1 sınıf öğretmeni ve 2 sınıf öğretmeni adayı atölyeye katılmıştır. Birer okul öncesi öğretmeni, okul öncesi öğretmen adayı ve sınıf öğretmen adayı bireysel olarak bilgi edinmiştir. Son olarak 14 okul öncesi öğretmeni, 14 okul öncesi öğretmen adayı, 11 sınıf öğretmeni ve 37 sınıf öğretmeni adayı ise herhangi bir eğitim almamıştır. Araştırmanın çalışma grubunda yer alan 80 okul öncesi öğretmeninden 72 si kadın, 8 i erkek; 51 okul öncesi öğretmen adayından 45 `i kadın 6`si erkek; 50 sınıf öğretmeninden 27 `si kadın 23 `u erkek; 88 sınıf öğretmeni adayından 48`i kadın 40`i erkektir. Okul öncesi öğretmenlerinin ortalama yaşı 30 ve ortalama mesleki deneyimi 8; sınıf öğretmenlerinin ortalama yaşı 34 ve ortalama mesleki deneyimi 11; her iki grup öğretmen adaylarının ise ortala yaşı 22 seklindedir.

\section{Veri Toplama Araçları}

Bu araştırmada veri toplama aracı olarak "Genel Bilgi Formu" ve "İlkokula Hazırlık Becerileri Anketi” kullanılmıştır.

Genel Bilgi Formu: Araştırmacılar tarafından hazırlanan Genel Bilgi Formunda; örnekleme dâhil edilen katılımcıların yaşı, cinsiyeti, mesleki deneyim, öğrenim durumu ve öğrenim gördükleri programa ilişkin 5 soru yer almaktadır.

İlkokula Hazırlık Becerileri Anketi: İlkokula Hazırlık Becerileri Anketi, öğretmenlerin ilkokula hazırlıkla ilgili becerilere ilişkin görüşlerini belirlemek üzere araştırmacılar tarafından geliştirilmiştir. 
İlkokula hazırlık için gerekli becerilerin neler olacağı belirlenmeden önce bir alan yazın taraması yapılmıştır (Chan, 2012; Dockett ve Perry, 2003; Janus, Duke ve Stat, 2005; National Education Goals Panel, NEGP, 1995; UNICEF, 2012). Daha sonra yedi okul öncesi öğretmeni, yedi birinci sınıf öğretmeni, dokuz okul öncesi öğretmen adayı ve dokuz sınıf öğretmeni adayından oluşan toplam 32 katılımcıya açık uçlu bir soru verilerek, soruya ilişkin düşüncelerini kompozisyon şeklinde yazmaları istenmiştir. Katılımcıların açık uçlu soruya verdikleri cevaplar araştırmacılar tarafından uygun gelişim alanlarına göre sınıflandırılarak listelenmiş ve anket maddelerinin oluşturulması sağlanmıştır. Bu şekilde altı alt boyut ve 57 maddeden oluşan taslak anket oluşturulmuştur. Taslak anket formu okul öncesi, sınıf öğretmenliği, ölçme değerlendirme ve Türk dili konularında çalışan alan uzmanlarının görüşüne sunularak dil ve kapsam geçerliği sağlanmıştır. Uzman görüşleri doğrultusunda 57 anket maddesi 26 madde olarak yeniden düzenlenmiştir. Ayrıca iki okul öncesi ve iki birinci sınıf öğretmeni ile iki okul öncesi öğretmen adayı ve iki sınıf öğretmeni adayı ile pilot çalışma yapılarak anket maddelerinin anlaşılırlığı kontrol edilmiştir. Pilot çalışma sonucunda anlaşılmayan üç madde ifade açısından yeniden düzenlenmiştir ve diğer maddelerin kalmasına karar verilmiştir. 26 maddeden oluşan ankete son şekli verilmiştir. 5'li Likert tipinde hazırlanan bu anket, ilkokula hazır bulunuşluğa ilişkin altı boyutu içermektedir. Bu boyutlar; "Fiziksel Gelişim", “Sosyal ve Duygusal Gelişim”, "Dil Gelişimi”, "Öğrenmeye Yönelik Yaklaşımlar”, "Bilişsel Gelişim” ve "Öz Bakım Becerileri” dir. Bu boyutlar, Amerika Ulusal Eğitim Hedefleri Paneli'nde (National Education Goals Panel, NEGP, 1995) belirlenen ilkokula hazırlıkla ilgili beş temel alana dayanmaktadir.

İlkokula Hazırlık Becerileri Anketinin Fiziksel gelişim boyutu 4; sosyal ve duygusal gelişim boyutu 6; dil gelişimi boyutu 4; öğrenmeye yönelik yaklaşımlar boyutu 3; bilişsel gelişim boyutu 4; ve öz bakım becerileri boyutu 5 madde içermektedir. Anket maddelerine verilecek yanıtlar; hiç katılmiyorum (1), katılmiyorum (2), kararsızım (3), katıliyorum (4), ve tamamen katıliyorum (5) şeklindedir. Anket, bireysel olarak uygulanmakta ve her bir anketin uygulanması yaklaşık 10 dakika sürmektedir.

\section{Veri Toplama Süreci}

Araştırmanın verileri 2017 - 2018 eğitim-öğretim yllında Şubat-Eylül aylarında Ankara ilindeki resmi ve özel okullarda görevli okul öncesi ve birinci sınıf öğretmenleri ile bir devlet üniversitesinin son sınıfına devam eden okul öncesi ve sınıf öğretmen adaylarından toplanmıştır.

Bu çalışma için Hacettepe Üniversitesi Senatosu Etik Komisyonunun 19.12.20179 tarihli 76942594900/59 sayılı kararı ile etik izin alınmıştır. Ardından araştırmacılar ilgili kurumların yöneticileri ile 
görüşerek, araştırmanın amacını açıklamışlardır. Öğretmenler ve öğretmen adayları ile çalışma yapılabilmesi için gerekli izin alınmıştır. Katılımcılar, çalışmaya katılımın gönülllülük esasına dayalı olduğu, çalışmaya katılmak isteyenlerin kişi ve kurum bilgilerinin istenmeyeceği ve hiçbir ortamda paylaşılmayacağı, kendilerine yöneltilecek soruların yalnızca görüş belirlemeye yönelik olacağı hakkında bilgilendirilmişlerdir. Araştırmaya katılmayı kabul eden öğretmen ve öğretmen adaylarına tercihleri doğrultusunda çevrimiçi anket formu ya da basılı anket formu verilerek, soruları cevaplamaları istenmiştir.

\section{Verilerin Analizi}

İlkokula Hazırlık Becerileri Anketinden elde edilen veriler tablolarda düzenlenerek frekans, yüzde ve ortalama kullanılarak betimlenmiş ve yorumlanmıştır.

\section{BULGULAR}

Bu bölümde, araştırmaya katılan okul öncesi öğretmenleri, birinci sınıf öğretmenleri ve öğretmen adaylarının ilkokula hazırlık becerileri anketine verdikleri cevaplardan elde edilen bulgulara ait tablolara yer verilmiştir. Tablo 2'de okul öncesi öğretmenlerinin ilkokula hazırlık becerilerine ilişkin görüşleri yer almaktadır.

Tablo 2. Okul Öncesi Öğretmenlerinin İlkokula Hazırlık Becerilerine İlişkin Görüşleri

\begin{tabular}{|c|c|c|c|c|c|c|}
\hline \multirow[t]{2}{*}{ İlkokula Hazırlık Becerileri } & \multicolumn{6}{|l|}{ O.Ö.Ö. } \\
\hline & $5(\%)$ & $4(\%)$ & $3(\%)$ & $2(\%)$ & $1(\%)$ & $\mathbf{X}$ \\
\hline \multicolumn{7}{|l|}{ Fiziksel Gelişim } \\
\hline Fiziksel olarak sağl1klı olma & 49 & 33 & 6 & 7 & 5 & 4,13 \\
\hline El göz koordinasyonuna sahip olma & 63 & 32 & 1 & 1 & 2 & 4,56 \\
\hline Yaşına uygun büyük kas becerilerine sahip olma & 58 & 28 & 5 & 6 & 3 & 4,37 \\
\hline \multirow[t]{2}{*}{ Yaşına uygun küçük kas becerilerine sahip olma } & 66 & 29 & 4 & 1 & 0 & 4,59 \\
\hline & & & & & & 4.41 \\
\hline \multicolumn{7}{|l|}{ Sosyal-Duygusal Gelişim } \\
\hline $\begin{array}{l}\text { Üzüldüğü, sevindiği ya da korktuğunda duygusunu doğru bir } \\
\text { șekilde ifade etme }\end{array}$ & 57 & 32 & 11 & 0 & 0 & 4,44 \\
\hline $\begin{array}{l}\text { Üzüldügünde, öfkelendiğinde ya da heyecanlandığında } \\
\text { kendi kendini sakinlestirme }\end{array}$ & 51 & 33 & 15 & 1 & 0 & 4,32 \\
\hline Empati kurma & 47 & 34 & 14 & 4 & 1 & 4,23 \\
\hline Olumlu akran ilişkileri kurma & 60 & 31 & 8 & 1 & 0 & 4,49 \\
\hline $\begin{array}{l}\text { Anne ve babadan ayrilma kaygısı yaşamadan okula uyum } \\
\text { sağlama }\end{array}$ & 69 & 27 & 3 & 1 & 0 & 4,63 \\
\hline \multirow[t]{2}{*}{ Öğretmenin yönergelerini takip etme } & 65 & 29 & 5 & 1 & 0 & 4,56 \\
\hline & & & & & & 4,44 \\
\hline \multicolumn{7}{|l|}{ Öğrenmeye Yönelik Yaklaşımlar } \\
\hline Kendi başına çalışma & 35 & 42 & 20 & 2 & 1 & 4,09 \\
\hline Öğrenmeye karşı istekli olma & 60 & 34 & 5 & 1 & 0 & 4,51 \\
\hline \multirow[t]{2}{*}{ Öğrenme sürecinde karşılaştığı sorunları çözme } & 56 & 36 & 7 & 1 & 0 & 4,46 \\
\hline & & & & & & 4,35 \\
\hline $\begin{array}{l}\text { n Çocukluk Çalışmaları Dergisi } \\
\text { Cilt } 4 \cdot \text { Sayı } 2 \cdot \text { Ekim }\end{array} 2020$ & $\begin{array}{l}\text { Journal } \\
\text { Volum }\end{array}$ & Issue & ctober & & & \\
\hline
\end{tabular}




\begin{tabular}{|c|c|c|c|c|c|c|}
\hline \multicolumn{7}{|l|}{ Dil Gelişimi } \\
\hline $\begin{array}{l}\text { Duygu ve düşüncelerini anlaşllır ve düzgün bir Türkçe ile } \\
\text { aktarma }\end{array}$ & 49 & 47 & 2 & 2 & 0 & 4,39 \\
\hline Okunan bir metin veya hikâyeyi anlama ve yorumlama & 48 & 42 & 7 & 1 & 1 & 4,36 \\
\hline Fonolojik farkındalığa sahip olma & 30 & 51 & 15 & 1 & 3 & 4,05 \\
\hline Yazma amaçlı karalamalar yapma & 43 & 42 & 11 & 2 & 2 & $\begin{array}{l}4,19 \\
4,24\end{array}$ \\
\hline \multicolumn{7}{|l|}{ Bilişsel Gelişim } \\
\hline Kavram bilgisine sahip olma & 61 & 33 & 3 & 2 & 1 & 4,50 \\
\hline Temel matematik becerilerine sahip olma & 53 & 37 & 6 & 2 & 2 & 4,37 \\
\hline $\begin{array}{l}\text { Nesneleri kullanarak 10' a kadar basit toplama ve çıarma } \\
\text { işlemleri yapma }\end{array}$ & 43 & 46 & 3 & 4 & 3 & 4,20 \\
\hline Olaylar arasında neden-sonuç ilişkisi kurma & 49 & 43 & 6 & 1 & 1 & $\begin{array}{l}4,36 \\
4,35\end{array}$ \\
\hline \multicolumn{7}{|l|}{ Özbakım Becerileri } \\
\hline Kendi kendine giyinme ve soyunma & 64 & 25 & 7 & 3 & 2 & 4,46 \\
\hline $\begin{array}{l}\text { Tuvalet ihtiyacını ve buna yönelik temizliğini kendi kendine } \\
\text { yapma }\end{array}$ & 76 & 15 & 8 & 0 & 1 & 4,65 \\
\hline Yemeklerini kendi başına dökmeden yeme & 57 & 28 & 10 & 3 & 2 & 4,35 \\
\hline Kendi eşyalarının sorumluluğunu alma & 65 & 26 & 6 & 1 & 2 & 4,53 \\
\hline \multirow[t]{2}{*}{ Bulunduğu ortamı düzenli bırakma } & 59 & 29 & 10 & 1 & 1 & 4,43 \\
\hline & & & & & & 4,48 \\
\hline
\end{tabular}

Tablo 2.'de de görüldüğü üzere, okul öncesi öğretmenlerinin ilkokula hazırlık becerilerine ilişkin görüşleri beceri alt boyutları kapsamında incelendiğinde, öğretmenlerin sırasıyla öz bakım becerileri boyutu $(X=4,48)$, sosyal duygusal gelişim boyutu $(X=4,44)$, fiziksel gelişim boyutu $(X=4,41)$, bilişsel gelişim boyutu $(X=4,35)$, öğrenmeye yönelik yaklaşımlar boyutu $(X=4,35)$ ve dil gelişimi boyutuna $(X=4,24)$ değindikleri belirlenmiştir.

Okul öncesi öğretmenlerinin İlkokula hazırlık becerilerine ilişkin görüşlerine alt boyutlarda yer alan beceriler kapsamında bakıldığında ise; öğretmenlerin fiziksel gelişimde "Yaşına uygun küçük kas becerilerine sahip olma” becerisine $(X=4,59)$, sosyal-duygusal gelişimde "Anne ve babadan ayrilma kaygısı yaşamadan okula uyum sağlama" becerisine $(X=4,63)$, öğrenmeye yönelik yaklaşımlarda “Öğrenmeye karşı istekli olma” becerisine $(X=4,51)$, dil gelişiminde "Duygu ve düşüncelerini anlaş1lır ve düzgün bir Türkçe ile aktarma" becerisine $(X=4,39)$, bilişsel gelişimde "Kavram bilgisine sahip olma" becerisine $(X=4,50)$ ve öz bakım becerilerinde "Tuvalet ihtiyacını ve buna yönelik temizliğini kendi kendine yapma” becerisine $(X=4,65)$ değindikleri görülmüştür.

Tablo 3. Birinci Sınıf Öğretmenlerinin İlkokula Hazırlık Becerilerine İlişkin Görüşleri

\begin{tabular}{|c|c|c|c|c|c|c|}
\hline İlkokula Hazırlık Becerileri & $\begin{array}{l}\text { S.Ö. } \\
5 \\
(\%)\end{array}$ & $\begin{array}{l}4 \\
(\%) \\
\end{array}$ & $\begin{array}{l}3 \\
(\%)\end{array}$ & $\begin{array}{l}2 \\
(\%) \\
\end{array}$ & $\begin{array}{l}1 \\
(\%)\end{array}$ & $\mathbf{X}$ \\
\hline \multicolumn{7}{|l|}{ Fiziksel Gelişim } \\
\hline Fiziksel olarak sağlıklı olma & 58 & 36 & 6 & 0 & 0 & 4,52 \\
\hline El göz koordinasyonuna sahip olma & 74 & 18 & 8 & 0 & 0 & 4,66 \\
\hline Yaşına uygun büyük kas becerilerine sahip olma & 58 & 36 & 6 & 0 & 0 & 4,52 \\
\hline \multirow[t]{2}{*}{ Yaşına uygun küçük kas becerilerine sahip olma } & 60 & 32 & 4 & 4 & 0 & 4,48 \\
\hline & & & & & & 4,54 \\
\hline
\end{tabular}




\begin{tabular}{|c|c|c|c|c|c|c|}
\hline \multicolumn{7}{|l|}{ Sosyal-Duygusal Gelişim } \\
\hline $\begin{array}{l}\text { Üzüldüğü, sevindiği ya da korktuğunda duygusunu doğru bir şekilde } \\
\text { ifade etme }\end{array}$ & 72 & 16 & 10 & 2 & 0 & 4,58 \\
\hline $\begin{array}{l}\text { Üzüldügüunde, öfkelendiğinde ya da heyecanlandığında kendi kendini } \\
\text { sakinleştirme }\end{array}$ & 50 & 34 & 12 & 2 & 2 & 4,28 \\
\hline Empati kurma & 58 & 20 & 16 & 4 & 2 & 4,28 \\
\hline Olumlu akran ilişkileri kurma & 68 & 24 & 4 & 4 & 0 & 4,56 \\
\hline Anne ve babadan ayrılma kaygısı yaşamadan okula uyum sağlama & 66 & 30 & 4 & 0 & 0 & 4,62 \\
\hline Öğretmenin yönergelerini takip etme & 72 & 26 & 2 & 0 & 0 & $\begin{array}{l}4,70 \\
4.50\end{array}$ \\
\hline \multicolumn{7}{|l|}{ Öğrenmeye Yönelik Yaklaşımlar } \\
\hline Kendi başına çalışma & 36 & 48 & 16 & 0 & 0 & 4,20 \\
\hline Öğrenmeye karşı istekli olma & 47 & 40 & 11 & 2 & 0 & 4,60 \\
\hline Öğrenme sürecinde karşılaştığ1 sorunları çözme & 50 & 40 & 10 & 0 & 0 & $\begin{array}{l}4,40 \\
4,40\end{array}$ \\
\hline \multicolumn{7}{|l|}{ Dil Gelişimi } \\
\hline Duygu ve düşüncelerini anlaşılır ve düzgün bir Türkçe ile aktarma & 62 & 24 & 12 & 2 & 0 & 4,46 \\
\hline Okunan bir metin veya hikâyeyi anlama ve yorumlama & 46 & 38 & 14 & 2 & 0 & 4,28 \\
\hline Fonolojik farkındalığa sahip olma & 44 & 26 & 24 & 4 & 2 & 4,06 \\
\hline Yazma amaçlı karalamalar yapma & 48 & 38 & 14 & 0 & 0 & $\begin{array}{l}4,30 \\
4,27\end{array}$ \\
\hline \multicolumn{7}{|l|}{ Bilişsel Gelişim } \\
\hline Kavram bilgisine sahip olma & 60 & 26 & 14 & 0 & 0 & 4,46 \\
\hline Temel matematik becerilerine sahip olma & 46 & 32 & 18 & 4 & 0 & 4,20 \\
\hline $\begin{array}{l}\text { Nesneleri kullanarak 10' a kadar basit toplama ve ç1karma işlemleri } \\
\text { yapma }\end{array}$ & 48 & 20 & 28 & 4 & 0 & 4,12 \\
\hline Olaylar arasında neden-sonuç ilişkisi kurma & 44 & 40 & 16 & 0 & 0 & $\begin{array}{l}4,28 \\
4,26\end{array}$ \\
\hline \multicolumn{7}{|l|}{ Özbakım Becerileri } \\
\hline Kendi kendine giyinme ve soyunma & 60 & 34 & 6 & 0 & 0 & 4,54 \\
\hline Tuvalet ihtiyacını ve buna yönelik temizliğini kendi kendine yapma & 76 & 20 & 4 & 0 & 0 & 4,72 \\
\hline Yemeklerini kendi başına dökmeden yeme & 72 & 22 & 6 & 0 & 0 & 4,66 \\
\hline Kendi eşyalarının sorumluluğunu alma & 72 & 24 & 4 & 0 & 0 & 4,68 \\
\hline Bulunduğu ortamı düzenli bırakma & 66 & 34 & 0 & 0 & 0 & $\begin{array}{l}4,62 \\
4,64\end{array}$ \\
\hline
\end{tabular}

Tablo 3.'den de anlaşılacağı üzere, birinci sınıf öğretmenlerinin ilkokula hazırlık becerilerine ilişkin görüssleri beceri alt boyutları kapsamında incelendiğinde öğretmenlerin sırasıyla öz bakım becerileri boyutu $(X=4,64)$, fiziksel gelişim boyutu $(X=4,54)$, sosyal-duygusal gelişim boyutu $(X=4,50)$, öğrenmeye yönelik yaklaşımlar boyutu $(X=4,40)$, dil gelişimi boyutu $(X=4,27)$ ve bilişsel gelişim boyutuna $(X=4,26)$ değindikleri görülmektedir.

Birinci sınıf öğretmenlerinin İlkokula hazırlık becerilerine ilişkin görüşlerine alt boyutlarda yer alan beceriler kapsamında bakıldığında ise; öğretmenlerin sırasıyla fiziksel gelişimde "El göz koordinasyonuna sahip olma" becerisine $(X=4,66)$, sosyal-duygusal gelişimde "Öğretmenin yönergelerini takip etme” becerisine $(X=4,70)$, ögrenmeye yönelik yaklaşımlarda “Öğrenmeye karşı istekli olma" becerisine $(X=4,60)$, dil gelişiminde "Duygu ve düşüncelerini anlaşllır ve düzgün bir Türkçe ile aktarma" becerisine $(X=4,46)$, bilişsel gelişimde "Kavram bilgisine sahip olma" becerisine $(X=4,46)$, ve öz bakım becerilerinde "Tuvalet ihtiyacını ve buna yönelik temizliğini kendi kendine yapma” becerisine $(X=4,72)$ değindikleri belirlenmiştir. 
Tablo 4. Okul Öncesi Öğretmen Adaylarının İlkokula Hazırlık Becerilerine İlişkin Görüşleri

\begin{tabular}{|c|c|c|c|c|c|c|}
\hline \multirow[t]{2}{*}{ İlkokula Hazırlık Becerileri } & \multicolumn{6}{|c|}{ O.Ö.Ö.A. } \\
\hline & $\begin{array}{l}5 \\
(\%)\end{array}$ & $\begin{array}{l}4 \\
(\%)\end{array}$ & $\begin{array}{l}3 \\
(\%)\end{array}$ & $\begin{array}{l}2 \\
(\%)\end{array}$ & $\begin{array}{l}1 \\
(\%)\end{array}$ & $x$ \\
\hline \multicolumn{7}{|l|}{ Fiziksel Gelişim } \\
\hline Fiziksel olarak sağlıklı olma & 67 & 22 & 10 & 2 & 0 & 4,53 \\
\hline El göz koordinasyonuna sahip olma & 51 & 43 & 4 & 2 & 0 & 4,43 \\
\hline Yaşına uygun büyük kas becerilerine sahip olma & 57 & 27 & 12 & 2 & 2 & 4,35 \\
\hline Yaşına uygun küçük kas becerilerine sahip olma & 57 & 37 & 23 & 3 & 0 & $\begin{array}{l}4,45 \\
4.44\end{array}$ \\
\hline \multicolumn{7}{|l|}{ Sosyal-Duygusal Gelişim } \\
\hline $\begin{array}{l}\text { Üzüldüğü, sevindiği ya da korktuğunda duygusunu doğru bir şekilde } \\
\text { ifade etme }\end{array}$ & 70 & 28 & 2 & 0 & 0 & 4,69 \\
\hline $\begin{array}{l}\text { Üzüldügüünde, öfkelendiğinde ya da heyecanlandığında kendi kendini } \\
\text { sakinleștirme }\end{array}$ & 53 & 23 & 18 & 2 & 4 & 4,20 \\
\hline Empati kurma & 55 & 25 & 14 & 4 & 2 & 4,27 \\
\hline Olumlu akran ilişkileri kurma & 65 & 31 & 2 & 2 & 0 & 4,57 \\
\hline Anne ve babadan ayrılma kaygısı yaşamadan okula uyum sağlama & 61 & 29 & 8 & 2 & 0 & 4,49 \\
\hline Öğretmenin yönergelerini takip etme & 59 & 37 & 4 & 0 & 0 & $\begin{array}{l}4,55 \\
4,46\end{array}$ \\
\hline \multicolumn{7}{|l|}{ Öğrenmeye Yönelik Yaklaşımlar } \\
\hline Kendi başına çalışma & 33 & 47 & 14 & 6 & 0 & 4,08 \\
\hline Öğrenmeye karşı istekli olma & 56 & 36 & 7 & 1 & 0 & 4,61 \\
\hline Öğrenme sürecinde karşılaştığı sorunları çözme & 47 & 40 & 12 & 1 & 0 & $\begin{array}{l}4,29 \\
4,32\end{array}$ \\
\hline \multicolumn{7}{|l|}{ Dil Gelişimi } \\
\hline Duygu ve düşüncelerini anlaşılır ve düzgün bir Türkçe ile aktarma & 51 & 39 & 10 & 0 & 0 & 4,41 \\
\hline Okunan bir metin veya hikâyeyi anlama ve yorumlama & 37 & 55 & 6 & 2 & 0 & 4,25 \\
\hline Fonolojik farkındalığa sahip olma & 39 & 31 & 21 & 6 & 2 & 4,00 \\
\hline Yazma amaçlı karalamalar yapma & 33 & 43 & 14 & 10 & 0 & $\begin{array}{l}4,00 \\
4,22\end{array}$ \\
\hline \multicolumn{7}{|l|}{ Bilişsel Gelişim } \\
\hline Kavram bilgisine sahip olma & 57 & 29 & 10 & 2 & 2 & 4,37 \\
\hline Temel matematik becerilerine sahip olma & 45 & 43 & 10 & 2 & 0 & 4,29 \\
\hline $\begin{array}{l}\text { Nesneleri kullanarak 10' a kadar basit toplama ve çıkarma işlemleri } \\
\text { yapma }\end{array}$ & 47 & 29 & 20 & 2 & 2 & 4,18 \\
\hline Olaylar arasında neden-sonuç ilişkisi kurma & 47 & 47 & 4 & 2 & 0 & $\begin{array}{l}4,37 \\
4,30\end{array}$ \\
\hline \multicolumn{7}{|l|}{ Özbakım Becerileri } \\
\hline Kendi kendine giyinme ve soyunma & 69 & 29 & 2 & 0 & 0 & 4,67 \\
\hline Tuvalet ihtiyacını ve buna yönelik temizliğini kendi kendine yapma & 80 & 18 & 2 & 0 & 0 & 4,78 \\
\hline Yemeklerini kendi başına dökmeden yeme & 70 & 25 & 5 & 0 & 0 & 4,67 \\
\hline Kendi eşyalarının sorumluluğunu alma & 72 & 18 & 10 & 0 & 0 & 4,63 \\
\hline Bulunduğu ortamı düzenli birakma & 74 & 19 & 4 & 3 & 0 & $\begin{array}{l}4,67 \\
4,68\end{array}$ \\
\hline
\end{tabular}

Tablo 4.'de sunulduğu üzere okul öncesi öğretmen adaylarının ilkokula hazırlık becerilerine ilişkin görüşleri beceri alt boyutlarına göre incelendiğinde öğretmen adaylarının sırasıyla; öz bakım becerileri boyutuna $(X=4,68)$, sosyal-duygusal gelişim boyutuna $(X=4,46)$, fiziksel gelişim boyutuna $(X=4,44)$, öğrenmeye yönelik yaklaşımlar boyutuna $(X=4,32)$, bilişsel gelişim boyutuna $(X=4,30)$ ve dil gelişimi boyutuna $(X=4,22)$ değindikleri görülmüştür. Okul öncesi öğretmen adaylarının İlkokula hazırlık becerilerine ilişkin görüşlerine alt boyutlarda yer alan beceriler kapsamında bakıldığında ise; okul öncesi öğretmen adaylarının sırasıyla fiziksel gelişimde "Fiziksel olarak sağlıklı olma” becerisine $(X=4,53)$, sosyal-duygusal gelişimde "Üzüldüğü, sevindiği ya da korktuğunda 
duygusunu doğru bir şekilde ifade etme" becerisine $(X=4,69)$, öğrenmeye yönelik yaklaşımlarda “Öğrenmeye karşı istekli olma" becerisine $(X=4,61)$, dil gelişiminde "Duygu ve düşüncelerini anlaş1lır ve düzgün bir Türkçe ile aktarma" becerisine $(X=4,41)$, bilişsel gelişimde "Kavram bilgisine sahip olma" $(X=4,37)$ ve "Olaylar arasında neden-sonuç ilişkisi kurma” becerisine $(X=4,37)$, ve özbakım becerilerinde ise "Tuvalet ihtiyacını ve buna yönelik temizliğini kendi kendine yapma" becerisine $(X=4,78)$ değindikleri saptanmıştır.

Tablo 5. Sınıf Öğretmeni Adaylarının İlkokula Hazırlık Becerilerine İlişkin Görüşleri

\begin{tabular}{|c|c|c|c|c|c|c|}
\hline \multirow[t]{2}{*}{ İlkokula Hazırlık Becerileri } & \multicolumn{6}{|c|}{ S.Ö.A. } \\
\hline & $\begin{array}{l}5 \\
(\%)\end{array}$ & $\begin{array}{l}4 \\
(\%)\end{array}$ & $\begin{array}{l}3 \\
(\%)\end{array}$ & $\begin{array}{l}2 \\
(\%)\end{array}$ & $\begin{array}{l}1 \\
(\%)\end{array}$ & $\mathbf{X}$ \\
\hline \multicolumn{7}{|l|}{ Fiziksel Gelişim } \\
\hline Fiziksel olarak sağlılı olma & 68 & 17 & 8 & 5 & 2 & 4,45 \\
\hline El göz koordinasyonuna sahip olma & 69 & 19 & 8 & 3 & 1 & 4,55 \\
\hline Yaşına uygun büyük kas becerilerine sahip olma & 74 & 20 & 5 & 1 & 0 & 4,69 \\
\hline Yaşına uygun küçük kas becerilerine sahip olma & 70 & 22 & 3 & 5 & 0 & $\begin{array}{l}4,58 \\
4.56\end{array}$ \\
\hline \multicolumn{7}{|l|}{ Sosyal-Duygusal Gelişim } \\
\hline $\begin{array}{l}\text { Üzüldüğü, sevindiği ya da korktuğunda duygusunu doğru bir şekilde } \\
\text { ifade etme }\end{array}$ & 61 & 31 & 5 & 3 & 0 & 4,50 \\
\hline $\begin{array}{l}\text { Üzüldügünde, öfkelendiğinde ya da heyecanlandığında kendi kendini } \\
\text { sakinleştirme }\end{array}$ & 56 & 30 & 12 & 1 & 1 & 4,38 \\
\hline Empati kurma & 51 & 29 & 16 & 4 & 0 & 4,28 \\
\hline Olumlu akran ilişkileri kurma & 60 & 27 & 11 & 2 & 0 & 4,47 \\
\hline Anne ve babadan ayrılma kaygısı yaşamadan okula uyum sağlama & 58 & 30 & 12 & 0 & 0 & 4,45 \\
\hline Öğretmenin yönergelerini takip etme & 58 & 27 & 15 & 0 & 0 & $\begin{array}{l}4,43 \\
4,41\end{array}$ \\
\hline \multicolumn{7}{|l|}{ Öğrenmeye Yönelik Yaklaşımlar } \\
\hline Kendi başına çalışma & 48 & 29 & 20 & 1 & 1 & 4,22 \\
\hline Öğrenmeye karşı istekli olma & 50 & 40 & 10 & 0 & 0 & 4,48 \\
\hline Öğrenme sürecinde karşılaştığı sorunları çözme & 49 & 34 & 15 & 2 & 0 & $\begin{array}{l}4,30 \\
4,33\end{array}$ \\
\hline \multicolumn{7}{|l|}{ Dil Gelişimi } \\
\hline Duygu ve düşüncelerini anlaşıllır ve düzgün bir Türkçe ile aktarma & 55 & 36 & 8 & 1 & 0 & 4,43 \\
\hline Okunan bir metin veya hikâyeyi anlama ve yorumlama & 45 & 34 & 13 & 7 & 1 & 4,15 \\
\hline Fonolojik farkındalığa sahip olma & 50 & 27 & 21 & 3 & 1 & 4,17 \\
\hline Yazma amaçlı karalamalar yapma & 44 & 32 & 17 & 6 & 1 & $\begin{array}{l}4,12 \\
4,21\end{array}$ \\
\hline \multicolumn{7}{|l|}{ Bilişsel Gelişim } \\
\hline Kavram bilgisine sahip olma & 51 & 32 & 13 & 3 & 1 & 4,28 \\
\hline Temel matematik becerilerine sahip olma & 43 & 28 & 25 & 4 & 0 & 4,11 \\
\hline $\begin{array}{l}\text { Nesneleri kullanarak 10' a kadar basit toplama ve çıkarma işlemleri } \\
\text { yapma }\end{array}$ & 43 & 28 & 15 & 14 & 0 & 3,98 \\
\hline Olaylar arasında neden-sonuç ilişkisi kurma & 50 & 34 & 10 & 4 & 2 & $\begin{array}{l}4,27 \\
4,16\end{array}$ \\
\hline \multicolumn{7}{|l|}{ Özbakım Becerileri } \\
\hline Kendi kendine giyinme ve soyunma & 68 & 23 & 7 & 1 & 1 & 4,56 \\
\hline Tuvalet ihtiyacını ve buna yönelik temizliğini kendi kendine yapma & 70 & 24 & 3 & 3 & 0 & 4,63 \\
\hline Yemeklerini kendi başına dökmeden yeme & 66 & 24 & 8 & 1 & 1 & 4,52 \\
\hline Kendi eşyalarının sorumluluğunu alma & 66 & 20 & 10 & 4 & 0 & 4,47 \\
\hline \multirow[t]{2}{*}{ Bulunduğu ortamı düzenli bırakma } & 66 & 20 & 9 & 4 & 1 & 4,56 \\
\hline & & & & & & 4,54 \\
\hline
\end{tabular}


Tablo 5'den de anlaşılacağı üzere sınıf öğretmeni adaylarının ilkokula hazırlık becerilerine ilişkin görüssleri beceri alt boyutlarına göre incelendiğinde sınıf öğretmen adaylarının sırasıyla fiziksel gelişim boyutuna $(X=4,56)$, Öz bakım becerileri boyutuna $(X=4,54)$, sosyal-duygusal gelişim boyutuna $(X=4,41)$, öğrenmeye yönelik yaklaşımlar boyutuna $(X=4,33)$, dil gelişimi boyutuna $(X=4,21)$, ve bilişsel gelişim boyutuna $(X=4,16)$ değindikleri görülmüştür.

Sınıf öğretmeni adaylarının İlkokula hazırlık becerilerine ilişkin görüşlerine alt boyutlarda yer alan beceriler kapsamında bakıldığında ise; öğretmen adaylarının sırasıyla fiziksel gelişimde "Yaşına uygun büyük kas becerilerine sahip olma" becerisine $(X=4,69)$, sosyal-duygusal gelişimde “Üzüldüğü, sevindiği ya da korktuğunda duygusunu doğru bir şekilde ifade etme” becerisine $(X=4,50)$, öğrenmeye yönelik yaklaşımlarda "Öğrenmeye karşı istekli olma” becerisine $(X=4,48)$, dil gelişiminde "Duygu ve düşüncelerini anlaşllır ve düzgün bir Türkçe ile aktarma” becerisine $(X=4,43)$, bilişsel gelişimde "Kavram bilgisine sahip olma" becerisine $(X=4,28)$, ve öz bakım becerilerinde "Tuvalet ihtiyacını ve buna yönelik temizliğini kendi kendine yapma" becerisine $(X=4,63)$ değindikleri belirlenmiştir.

\section{SONUÇ ve TARTIŞMA}

Araştırmada okul öncesi öğretmenlerinin ilkokula hazırlık becerilerine ilişkin görüşleri beceri alt boyutları kapsamında incelendiğinde, öğretmenlerin becerilere verdiği öncelik sırası öz bakım becerileri boyutu, sosyal duygusal gelişim boyutu, fiziksel gelişim boyutu, bilişsel gelişim boyutu, öğrenmeye yönelik yaklaşımlar boyutu ve dil gelişimi boyutuna değindikleri belirlenmiştir. Alanyazında yapılmış çalışmaların sonuçları incelendiğinde okul öncesi öğretmenlerinin okula hazırlık becerilerine ilişkin farklı görüşlerinin olduğu saptanmıştır. Piotrkowski, Botsko ve Matthews (2000) araştırmalarında okul öncesi öğretmenlerinin çocukların okula geçişleri için sağlıklı olmaları ve sosyal olarak yetkin olmaları gerektiğini vurgulamışlardır. Çalışmada öğretmenler ayrıca, bir çocuğun iletişim kurabilmesi ve temel bilgi ve becerilere sahip olmasının öğrenmeye olan yaklaşımından daha önemli olduğunu belirtmişlerdir. Lin, Lawrence ve Gorrell (2003) ve Dockett ve Perry (2002) de ise; okul öncesi öğretmenlerinin çocukların okula geçişleri için daha çok çocuğun sosyal gelişimine vurgu yapılmıştır. Erkan, Koyuncu Şahin ve Atış-Akyol (2017) okul öncesi öğretmenlerinin ve okul öncesi öğretmen adaylarının ilkokula hazırlığa ilişkin görüşlerini inceledikleri araştırmada, çocukların ilkokula hazırlık için sahip olması gereken becerilere ilişkin olarak okul öncesi öğretmenlerin çocukların fiziksel iyilik halleri ve motor gelişimleri üzerine odaklandıkları görülmüştür. Okul olgunluğuna ulaşmış bir çocuğun gösterdiği özelliklere ilişkin öğretmen görüşlerinin yer aldığı bir çalışmada da “fiziksel ve zihinsel becerileri gösterme” en çok 
vurgulanan gelişim alanıdır (Güzel ve Özyurt, 2018). Araştırmalara dayanarak, yurtdışında yapılan çalışmalarda daha çok sosyal gelişim alanına vurgu yapılırken Türkiye'deki öğretmenlerin özbakım ve fiziksel gelissimi ilkokula hazırlık için önem gördügü çıkarımı yapılabilir. Bunun nedeni farklı kültürlerde farklı hedeflerin önemli görülmesi ile açıklanabilir. Bazı çalışmalarda ise okulöncesi öğretmenleri, çocukların okula geçişleri için tüm gelişim alanlarında olgunluğa ulaşmış olmaları gerektiği belirtilmektedir (Kutluca Canbulat ve Yıldızbaş, 2015; Şahin, Sak, Tuncer, 2013).

Araştırmanın bir diğer sonucunda, birinci sınıf öğretmenlerinin ilkokula hazırlık becerilerine ilişkin görüşleri beceri alt boyutlan kapsamında incelendiğinde öğretmenlerin becerilere verdiği öncelik sırası, Öz bakım becerileri boyutu, fiziksel gelişim boyutu, sosyal-duygusal gelişim boyutu, öğrenmeye yönelik yaklaşımlar boyutu, dil gelişimi boyutu ve bilişsel gelişim boyutuna değindikleri tespit edilmiştir. Araştırma bulgusunun aksine Koçyiğit ve Saban (2014) ilköğretim birinci sınıf öğretmenleri ve ebeveynleri ile yaptıkları çalışmada okula hazırbulunuşluk için öğretmenlerin diğer becerilere oranla sosyal beceriler üzerinde durduklarını saptamıslardır. Kutluca Canbulat ve Yıldızbaş'ın (2015) çalışmasında ise; sınıf öğretmenlerinin çocukların gelişim alanlarının hepsinde okula hazır olması gerektiği vurgulanmıştır. Araştırmalarda sınıf öğretmenlerinin ilkokula hazırbulunuşluk ile ilgili beklentileri çeşitlilik göstermekle birlikte bazı araştırmalardaki katılımcılar daha özel gelişim alanlarına vurgu yaparken bazı araştırmalardaki katılımcılar ise okula hazırlığ1 bütünsel gelişimin desteklenmesi olarak değerlendirilmektedir. Bu farklılıkların öğretmenlerin mesleki hedeflerinde gelişim için öncelik verdikleri alanlar ile ve/veya meslek hayatlarındaki tecrübeleri ile ilişkili olduğu düşünülmektedir.

Ayrıca araştırmada okul öncesi öğretmen adaylarının ilkokula hazırlık becerilerine ilişkin görüşleri beceri alt boyutları kapsamında incelendiğinde öğretmen adaylarının sırasıyla öz bakım becerileri boyutuna, sosyal-duygusal gelişim boyutuna, fiziksel gelişim boyutuna, öğrenmeye yönelik yaklaşımlar boyutuna, bilişsel gelişim boyutuna, ve dil gelişimi boyutuna değindikleri bulunmuştur. Araştırma sonucunun aksine Erkan, Koyuncu Şahin ve Atış-Akyol (2017) yaptıkları çalışmada okul öncesi öğretmen adaylarının ilkokula hazırlık için birinci sırada sosyal-duygusal gelişime önem verdiklerini bulmuşlardır. Araştırmanın bulgusuna paralel olarak Chan (2012) çalışmasında okul öncesi öğretmenleri öz bakım becerilerini birinci öncelikli olarak belirlemişlerdir. Araştırmanın bu sonucu okul öncesi dönem çocukların gelişimsel özellikleri düşünüldüğ̈̈nde özbakım becerilerinin (kendi kendine tuvaletini hijyen kurallarına uygun şekilde yapabilme, yemeğini yiyebilme, ayakkabısını giyebilme vb.) geliştirilmesinin, okul öncesi eğitim kurumlarındaki diğer eğitim ve öğretim faaliyetlerini kolaylaştıracağına yönelik beklentiden kaynaklandığı düşünülmektedir. 
Sınıf öğretmeni adaylarının ilkokula hazırlık becerilerine ilişkin görüşleri beceri alt boyutlarına göre incelendiğinde ise sınıf öğretmen adaylarının sırasıyla; fiziksel gelişim boyutuna, öz bakım becerileri boyutuna, sosyal-duygusal gelişim boyutuna, öğrenmeye yönelik yaklaşımlar boyutuna, dil gelissimi boyutuna ve bilişsel gelişim boyutuna değindikleri görülmüştür. İncelenen alanyazında sınıf öğretmeni adayları ile ilkokula hazırlık becerilerine ilişkin yapılmış bir çalışmaya rastlanmamıştır. Ancak; ailelerle yapılan bir çalışmada araştırmanın bulgusuna paralel olarak, ilkokula hazırlık becerilerinde fiziksel gelişim becerilerine vurgu yapıldığı görülmektedir (Ertürk Kara ve Gözcü, 2015).

Bir diğer araştırma sonucuna göre, okul öncesi öğretmenleri, birinci sınıf öğretmenleri, okul öncesi öğretmen adayları ve sınıf öğretmeni adaylarının ilkokula hazırlık becerileri ile ilgili olarak alt boyutlarda yer alan bazı ortak becerilere değindikleri görülmektedir. Öğrenmeye yönelik yaklaşımlar boyutunda "Öğrenmeye karşı istekli olma" becerisinin; dil gelişimi boyutunda "Duygu ve düşüncelerini anlaşlır ve düzgün bir Türkçe ile aktarma” becerisinin ve öz bakım becerileri boyutunda "Tuvalet ihtiyacını ve buna yönelik temizliğini kendi kendine yapma" becerisinin ortak olduğu tespit edilmiştir. Chan (2012) yaptığı araştırmada araştırmanın bulgusuna paralel olarak, ilkokulu öğretmenlerinin öğrenmeye yönelik beceriler alt boyutunda en yüksek ortalamanın "okumaya karşı istekli olma” becerisinde olduğu görülmektedir. Bilişsel gelişim boyutunda; "Kavram bilgisine sahip olma” becerisinin okul öncesi öğretmenleri, birinci sınıf öğretmenleri ve sınıf öğretmeni adayları tarafindan en yüksek ortalamaya sahip beceri olarak belirlendiği, farklı olarak okul öncesi öğretmen adayların bu boyutta en yüksek ortalamaya sahip beceri olarak "Olaylar arasında neden-sonuç ilişkisi kurma” becerisini belirlediği görülmektedir. Sosyal duygusal gelişim boyutunda; okul öncesi ve sınıf öğretmen adayları "Üzüldüğü, sevindiği ya da korktuğunda duygusunu doğru bir şekilde ifade etme” becerisine, okul öncesi öğretmenleri “Anne ve babadan ayrılma kaygısı yaşamadan okula uyum sağlama” becerisine, birinci sınıf öğretmenleri “Öğretmenin yönergelerini takip etme" becerisine en yüksek ortalamayı vermişlerdir. Chan (2012) yaptığ1 çalışmada sosyal duygusal gelişim alanında okul öncesi öğretmenleri en çok "içsel motivasyon" becerisine, ilkokul öğretmenleri ise en çok "temel sosyal davranışlar ile duygularını uygun şekilde ifade edebilme" becerilerine en yüksek puanı vermişlerdir. Fiziksel gelişim boyutunda katılımcılar farklı becerilere en yüksek puanı vermişlerdir.

İlkokula hazırlık becerileri alt boyutları toplam puan ortalamasına bakıldığında ise; okul öncesi öğretmenleri, birinci sinıf öğretmenleri ve okul öncesi öğretmen adaylar1 en yüksek ortalamay1 “öz bakım becerisi” boyutuna verirken, sınıf öğretmen adayları "fiziksel gelişim” boyutuna en yüksek ortalamayı vermişlerdir. Araştırmanın bulgusuna paralel olarak Yeşil Dağlı (2013) çocuğu okul 
öncesi eğitim kurumuna giden velilerin okula hazırlığa ilişkin görüşlerini incelediği çalışmasında, velilerin tamamına yakınının çocukların öz bakım becerilerini kazanmış olmasını ve kişisel ihtiyaç ve isteklerini ifade edebilmesini önemsediklerini bulmuştur. Araştırmanın bu bulgusunun aksine alan yazında ilkokula hazırlık becerilerinde diğer becerilere oranla akademik becerilerin önemini vurgulayan çalışmalarda (Lewit ve Baker, 1995; Williamson, 2003, Kwong, 2006; Skeete, 2006) yer almaktadır.

Araştırma sonuçları, alan yazında ilkokula hazırlık becerileri ile ilgili farklı katılımcı grupları ile yapılan çalışmalarla birlikte yorumlandığında, ilkokula hazırlık becerilerinin alt boyutlarının önem sırasında benzerlikler kadar farklılıklar da olduğu görülmektedir. Katılımcıların farklı görüşlere sahip olmalarının ilkokula hazırlık kavramının yapısından kaynaklandığı düşünülmektedir. Çünkü ilkokula hazırlık kavramı, aile, öğretmen (okul öncesi öğretmeni, ilkokul öğretmeni), çocuk ve toplum gibi paydaşlardan oluşan ve tüm gelişim alanları ile çocuğun desteklenmesi gerektiğini vurgulayan bir kavramdır. Bu nedenle söz konusu farklılıklar örneklem gruplarının kendi deneyim ve beklentilerinden kaynaklanıyor olabilir. Daha sonra yapılacak olan çalışmalarda öğretmenlerin deneyimleri yaşadıkları örnekler üzerinden incelenerek yorumlanabilir. Ayrıca daha bütüncül bakılabilmesi için yapılacak araştırmalarda, okula hazırlığın tüm paydaşlarının görüşlerinin birlikte aynı ölçme aracı ile incelendiği çalışmaların sayısı artırılabilir.

\section{KAYNAKÇA}

Alexander, K. L., \& Entwisle, D.R. (1988). Achievement in the first two years of school: Patterns and processes. Monographs of the Society for Research in Child Development (Serial No. 218), 53(2), $1-157$.

Balaban, N. (1985). Starting school: From separation to independence. New York, NY:Teachers College Press.

Chan, W. L. (2012) Expectations for the transition from kindergarten to primary school amongst teachers, parents and children, Early Child Development and Care, 182:5, 639-664, DOI: 10.1080/03004430.2011.569543

Dereli, E. (2012). Okulöncesi öğretmenleri ile ilköğretim birinci sınıf öğretmenlerinin ilköğretime hazırlık süreci ile ilgili görüşlerinin karşılaştırılarak incelenmesi. Akademik Bakış Dergisi,30, $1-20$.

Dockett, S., \& Perry, B. (2002). Beliefs and expectations of parents, prior-to-school educators and schoolteachers as children start school: An Australian perspective. (ERIC Document Number: 465440).

Dockett, S., \& Perry, B. (2003). The transition to school: What's important? Educational Leadership, 60(7), 30-34.

Edgar, D. (1986). Family background and the transition to school. Primary Education, 17(4),16-21. 
Erden, F. T., \& Altun, D. (2014). Sınıf öğretmenlerinin okul öncesi eğitim ve ilköğretime geçiş süreci hakkıındaki görüşlerinin incelenmesi. İlkögretim Online, 13(2), 481-502.

Erkan S. (2011). Farklı sosyoekonomik düzeydeki ilköğretim birinci sınıf öğrencilerinin okula hazırbulunuşluklarının incelenmesi. Hacettepe Üniversitesi Ë̆gitim Fakültesi Dergisi. 40, 186-197.

Erkan, S. \& Kırca, A. (2010). Okul öncesi eğitimin ilköğretim birinci sınıf öğrencilerinin okula hazırbulunuşluklarına etkisinin incelenmesi. Hacettepe Üniversitesi Ë̆itim Fakültesi Dergisi, 38 , 94-106.

Erkan, S., Koyuncu Şahin, M., \& Atış-Akyol, N. (2017). Okul öncesi öğretmenleri ve öğretmen adaylarının ilkokula hazırlıkla ilgili görüssleri. F. Temel(Ed.), 5. Okul Öncesi Eğitim Kongresi bildiri özet kitabr içinde (471-472). Ankara: Gazi Üniversitesi.

Ertürk Kara, H. G., \& Gözcü, S. (2015). Okula hazır olma konusunda öğretmen ve aile görüşleri: bir olgu bilim çalışması. Journal of Kirsebir Education Faculty, 16(2).

Gay, L. R., Mills, G. E., \& Airasian, P. W. (2009). Educational research: Competencies for analysis and applications. Upper Saddle River, N.J: Merrill/Pearson.

Janus, M., Duku, E.K. \& Stat, E. (2005). Development of the Short Early Development Instrument (S-EDI). Report for the World Bank.

Kagan, S. L., Moore, E., \& Bredekamp, S. (Eds.). (1995). Reconsidering children's early development and learning: Toward shared beliefs and vocabulary. Washington, DC: National Education Goals Panel.

Koçyığıt, S., \& Saban, A. (2014). Birinci sınıf öğretmenlerinin ve ebeveynlerin görüşlerine göre okula hazır bulunuşluk. Kuramsal Ë̆itimbilim Dergisi, 7(3), 322-341.

Kutluca Canbulat, A. N. \& Yıldızbaş F. (2015). Okul öncesi ve sınıf öğretmenlerinin 60-72 aylık çocukların okula hazır bulunuşluklarına ilişkin görüşleri. Abant İzæet Baysal Eğitim Fakültesi Dergisi. 14(1), 33-50. DOI: 10.17240/aibuefd.2014.14.1-5000091501

Kwong, C. L. Y. (2006). Taiwanese parents' and kindergarten teachers' expectations for children's school readiness skills. Unpublished doctoral dissertation, University of Alabama at Birmingham. (ProQuest UMI Dissertation Publishing Number: 3253058).

Lewit, E. M., \& Baker, L. S. (1995). School readiness. Future of Children, 5(2), 128-139.

Lin, H., Lawrence, F.R., \& Gorrell, J. (2003). Kindergarten teachers' views of children's readiness for school. Early Childhood Research Quarterly, 18, 225-237.

MEB (2013). Okul öncesi eğitim programı. Ankara: Milli Eğitim Bakanlığı.

Okagaki, L., \& Diamond, K.E. (2000). Responding to cultural and linguistic differences in the beliefs and practices of families with young children. Young Children, 55(3), 74-80.

Opper, S. (1993). Development of Hong Kong preschool. Hong Kong: Faculty of Education, University of Hong Kong. 
Özyurt, M., \& Güzel, N. (2018). Okul Öncesi Eğitimi Alan Çocukların Okul Olgunluğu Düzeylerinin ve Okul Olgunluğuna İlişkin Öğretmen Görüşlerinin İncelenmesi. Mersin Üniversitesi Ĕ̈itim Fakültesi Dergisi, 14(3), 1250-1267. DOI: 10.17860/mersinefd.441260

Piotrkowski, C. S., Botsko, M., \& Matthews, E. (2000). Parents' and teachers' beliefs about children's school readiness in a high-need community. Early Childhood Research Quarterly, 15(4), 537-558.

Piotrkowski, C.S. (2004). A community-based approach to school readiness in Head Start. In E. Zigler \& S.J. Styfco (Eds.), The Head Start debates (pp. 129-142). Baltimore, MD: Paul H. Brookes.

Ramey, S.L., \& Ramey, C.T. (1994). The transition to school: Why the first few years matter for a lifetime. Phi Delta Kappan, 76(3), 194-198.

Skeete, T. D. (2006). School readiness and assessment of young children: Implications for policy and practice. (ERIC Reproduction No: ED 437159).

Şahin B. (2014). Metodoloji. Tanrı̈rren A.(Ed.), Bilimsel araştırma yöntemleri, Ankara:Anı Yayınc1lık

Şahin, İ. T., Sak, R., \& Tuncer, N. (2013). Okul öncesi ve birinci sınıf öğretmenlerinin ilköğretime hazırlık sürecine ilişkin görüşlerinin karşılaştırılması. Kuram ve Uygulamada Eüitim Bilimleri, 13(3), 1691-1713.

Tantekin Erden F., Altun D. (2014). Sınıf öğretmenlerinin okul öncesi eğitim ve ilköğretime geçiş süreci hakkındaki görüşlerinin incelenmesi, İlk:ögretim Online, 13(2), 481-502.

UNICEF (2012). School Readiness: a conceptual framework. United Nations Children's Fund, New York.

Williamson, D. E. (2003). Readiness for School: A Study of Parent, Teacher, and Preschoolers School Readiness. Unpublished doctoral dissertation, Florida International University. (ProQuest UMI Dissertation Publishing Number: 3115859).

Wong, N.C. (2003). A study of children's difficulties in transition to school in Hong Kong. Early Child Development and Care, 173(1), 83-96.

Yeşil Dağlı, Ü. (2013). Çocukları okul öncesi eğitim kurumlarına devam eden velilerin ilkokula hazırbulunuşluk ile ilgili görüşleri. Ekev Akademi Dergisi, 16, 52. 